\title{
ANALISIS KEMAMPUAN KOORDINASI DAN KECEPATAN REAKSI SISWA TUNA GRAHITA DAN AUTIS (STUDI KASUS DI SLB NEGERI AUTIS CENTER) KOTA BENGKULU
}

\section{ADE ANDRI SETIAWAN}

\author{
PENJAS FKIP UNIB, e-mail: adeandrisetiawan07@gmali.com
}

\author{
Syafrial \\ Universitas Bengkulu \\ Defliyanto \\ Universitas Bengkulu
}

\begin{abstract}
Abstrak
Penelitian ini bertujuan Untuk mengetahui hasil koordinasi siswa tuna grahita dan autis di SLB Negeri Autis Center Kota Bengkulu, Untuk mengetahui hasil kecepatan reaksi siswa tuna grahita dan autis di SLB Negeri Autis Center Kota Bengkulu, Mengetahui hubungan kemampuan koordinasi dan kecepatan reaksi siswa tuna grahita dan autis di SLB Negeri Autis Center Kota Bengkulu, Untuk mengetahui perbedaan kemampuan koordinasi dan kecepatan reaksi antara SD Negeri 50 (Anak Normal) dengan Siswa SLB Negeri Autis Center (Anak Berkebutuhan Khusus) Kota Bengkulu. Penelitian ini dilakukan di SLB Negeri Autis Center Kota Bengkulu dan SD Negeri 50 Kota Bengkulu. Metode yang digunakan yaitu dengan menggunakan tes kemampuan koordinasi dan kecepatan reaksi. Subjek didalam penelitian ini nanti adalah siswa tuna grahita 20 orang, anak autis 10 orang dan untuk memperkaya analisis jadi dicari juga hasil perbedaan koordinasi dan kecepatan reaksi antara anak normal (SD Negeri 50 Kota Bengkulu) sebanyak 30 orang dengan anak berkebutuhan khusus (SLB Negeri Autis Center Kota Bengkulu) sebanyak 30 orang jadi semuanya sebanyak 60 orang yang akan diteliti. Adapun hasil penelitian hubungan koordinasi dan kecepatan reaksi anak berkebutuhan khusus yaitu $r_{\text {hitung }}$ lebih besar dari pada $r_{\text {tabel }}$ dimana $r_{\text {hitung }}=0,718>r_{\text {tabel }}=0,361$. Perbedaan koordinasi anak normal dengan anak berkebutuhan khusus yaitu $t$ hitung lebih besar dari pada nilai $t$ tabel $(14,43>1,697)$, dan hasil perbedaan kecepatan reaksi anak normal dengan anak berkebutuhan khusus yaitu thitung lebih besar dari pada nilai t tabel $(14,43>1,697)$
\end{abstract}

Kata Kunci : Koordinasi dan Kecepatan Reaksi

\begin{abstract}
The purpose of this research is to know the result of coordination of students with mental and autism in SLB Country Autism Center of Bengkulu City, To know the result of reaction speed of students of tuna grahita and autism in SLB Country Autism Center of Bengkulu City, to know the correlation of coordination ability and reaction speed of students with visual and autism In SLB Negeri Autis Center of Bengkulu city, to know the difference of coordination ability and speed of reaction between SD Negeri 50 (Normal Children) with SLB Students Affairs Autism Center (Children with Special Needs) Bengkulu City. This research was conducted at SLB Negeri Autis Center Kota Bengkulu and SD Negeri 50 Bengkulu city. The method used is by using the ability of coordination test and reaction speed. The subjects in this study will be 20 students, 10 children
\end{abstract}


autistic children and to enrich the analysis so searched also results of differences in coordination and speed of reaction between normal children (SD Negeri 50 Bengkulu city) as many as 30 people with children with special needs (SLB Negeri Autis Center City Bengkulu) as many as 30 people so everything as much as 60 people will be studied. The result of research of coordination relationship and speed of reaction of children with special requirement that is rhitung bigger than at rtabel where rhitung $=0,718>$ rtabel $=0,361$. Differences in the coordination of normal children with special needs children $t$ count greater than the value of $t$ table $(14,43>1,697)$, and the difference result of normal child reaction speed with children with special requirement that is $t$ bigger than $t$ value of table $(14,43>1,697)$.

\section{Keywords: Coordination and Speed of Reaction}

\section{PENDAHULUAN}

Sherril dalam Abdoellah (1996:3) menyatakan pendidikan jasmani khusus didefinisikan sebagai satu system penyampaian pelayan yang komprensif yang dirancang untuk mengidentifikas dan memecahkan masalah dalam ranah psikomotor. Pelayanan tersebut mencakup penilaian, program pendidikan individual (PPI), pengajaran bersifat pengembangan dan yang diarahkan, konseling, dan koordinasi dari sumber layanan yang terkait untuk memberikan pengalaman pendidikan jasmani yang optimal kepada anak dan pemuda.

Hakekat pembelajaran adaptif adalah meupakan pembelajaran biasa yang dimodifikasi dan dirancang sedemikian rupa sehingga dapat dipelajari, dilaksanakan, dan memenuhi kebutuhan pendidikan pembelajaran Anak Luar Biasa (anak berkebutuhan khusus) dengan demikian dapat dikatakan pembelajaran adaptif bagi anak luar biasa yaitu pendidikan luar biasa (PLB). Pendidikan luar biasa tersebut dirancang diadapatasikan sesuai karakteristik yang dimiliki oleh masing-masing anak. Ada tiga komponen rancangan dalam pendidikan luar biasa yakni sebagai berikut, pokok kelas, program dan layanan. Ketiga komponen tersebut bila dirancang dengan baik dan sempurna akan dapat memenuhi kebutuhan pendidikan bagi anak luar biasa. Pendidlkan luar biasa yang dalam bahasa Inggris disebut "Spesial Education", maka tidak bisa lepas dengan anak luar biasa yang dikenal juga dengan istilah anak cacat, anak berkelainan, anak tuna dan dalam pembelajarannya menjadi salah satu kelompok anak yang memiliki kebutuhan khusus. Istilah yang paling tepat tergantung dari mana kita memandang. Seperti dalam bahasa Inggris dikenal dengan istilah impairment, disability, handicap.

Pengertian untuk masing-masing dalam istilah diatas, Impairment berhubungan dengan penyakit dan kelainan pada jaringan, Disability berhubungan dengan kekurangan dan kekurangan fungsi atau tidak adanya bagian tubuh tertentu, sedangkan Handicap berhubungan dengan kelainan dan ketidak mampuan yang dimiliki seseorang bila berinteraksi dengan lingkungan. Anak luar biasa (anak berkebutuhan khusus) adalah anak yang memiliki kelianan pada fisik, mental, tingkah laku (behavioral) atau indranya memiliki kelainan yang sedemikian rupa sehingga didalam mengembangkan kemampuannya secara maksimum membutuhkan pendidikan luar biasa dengan demikian pada akhirnya sekarang ini perkembangan anak luar biasa 
sudah mulai dianggap sebagai manusia biasa sama seperti yang lain. Mereka memiliki hak yang sama dan ini menimbulkan perlakuan yang wajar seperti pada anak yang lain, yakni di didik dan di sekolahkan. Anak tuna grahita secara umum mempunyai tingkat kemampuan intelektual dibawah rata-rata (Delphie, 2006:15). Tuna grahita (reterdasi mental) adalah anak yang secara nyata mengalami hambatan dan keterbelakangan perkembangan mental intelektual jauh dibawah rata-rata sedemikian rupa sehingga mengalami kesulitan dalam tugas-tugas akademik, komunikasi maupun sosial, karenanya memerlukan layanan pendidikan khusus.

Tuna grahita mengacu pada fungsi intelektual umum secara intelektual umumyang secara signifikan berada dibawah rata-rata normal. Disamping itu tunagrahita mengalami kekurangan dalam tingkah laku dan penyesuaian, hal tersebut berlangsung atau terjadi masa perkembangannya. Dengan demikian sorang tuna grahita dikatakan apabila memiliki tiga faktor: 1). Keterlambatan fungsi kecerdasan atau dibawah rata-rata, 2). Ketidakmampuan dalam perilaku adaptif, 3). Terjadi selama perkembangan sampai usia 18 tahun. Klasifikasi yang digunakan sekarang adalah yang dikemukakan American Association on Mental Defficiency (Hallahan 1982, dalam Wardani, 2007:66-68) sebagai berikut: a). Mild menal retardation (tuna grahita IQ-nya 70-55 ringan), b). Moderate retardation (tuna grahita IQ-nya 55-40 sedang), Severe mental retardation (tuna grahita IQ-nya 40-25 berat) c). Profound mental retardation (sangat IQnya 25 kebawah berat). Anak autis merupakan bagian integral dari anak berkebutuhan khusus (ABK). Anak autis adalah anak yang mengalami gangauan perkembangan yang berat antara lain mempengaruhi cara seseorang untuk berkomunikasi dan berhubungan dengan orang lain. Hadis (2006:43) mengemukakan bahwa autistik merupakan gangguan yang berentetan atau perpasif gangguan perkembangan ini terjadi jelas pada masa bayi, masa anak-anak, dan remaja. Menurut Moh. Ali (2009:53-54) secara umum anak autistik mengalami kelainan dalam berbicara, disamping itu mengalami ganguan pada kemampuan intelektual serta fungsi syaraf.

$\mathrm{Hal}$ ini disebut dapat terlihat dengan adanya keganjilan perilaku dan ketidakmampuan berinteraksi dengan lingkungan masyarakat sekitarnya rincian tentang kelainan anak autistik sebagai berikut: kelainan berbicara keterlambatan serta penyimpangan dalam berbicara menyebabkan anak autistik sukar berkomunikasi serta tidak mampu memahami percakapan orang lain, fungsi syaraf dan intelektual, umunya anak autistik mengalami keterbelakangan mental, kebanyakan mempunyai skor IQ 50. Mereka tergolong tidak mempunyai kecakapan untuk memahami kecakapan untuk memahami benda-benda abstrak atau simbolik, namun di sisi lain mereka mampu memecahkan tekateki yang rumit dan mampu mengalikan suatu bilangan, perilaku yang ganjil, anak autis akan mudah sekali marah bila ada perubahan yang dilakukan pada situasi atau lingkungan dimana ia berada walau sekecil apapun, interaksi social, anak autistik kurang suka bergaul dan sangat terisolasi dari lingkungan hidupnya, terlihat kurang ceria, tidak pernah menaruh perhatian atau keinginan untuk menghargai perasaan orang lain, suka menghindar dengan orang lain sekalipun itu saudaranya sendiri.

Koordinasi adalah kemampuan melakukan gerak pada berbagai tingkat kesukaran dengan cepat dan tepat secara efisien (Irianto 2002, Dalam Pramugar, 2016:9). Koordinasi kemampuan siswa untuk 
merangkaikan beberapa gerakan untuk menjadi suatu gerakan yang selaras sesuai dengan tujuan. Ketrampilan biasanya melibatkan koordinasi dua organ pada tubuh, koordinasi antara mata dan tangan. Pada keterampilan yang melibatkan koordinasi mata dengan organ tubuh lain mutlak dibutuhkan. Keterampilan sendiri biasanya melibatkan koordinasi antara dua organ tubuh, diantaranya adalah koordinasi mata dan tangan yang mengkombinasikan antara kemampuan melihat dan keterampilan tangan. Kecepatan merupakan kemampuan seseorang untuk mengerjakan gerakan berkesinambungan dalam bentuk yang sama dengan waktu yang sesingkat-singkatnya. Kecepatan sangat dibutuhkan dalam olahraga dan dalam kehidupan sehari-hari yang mengandalkan kecepatan. Harsono dalam Wina, (2011:16) menyatakan kecepatan adalah kemampuan untuk melakukan gerakan-gerakan yang sejenis secara berturut-turut dalam waktu yang sesingkatsingkatnya. Dalam latihan kecepatan ini terdapat faktor-faktor yang tidakbisa diabaikan dalam pelatihannya. Faktor-faktor tersebut adalah kekuatan, waktu reaksi dan fleksibel. Siswa SLB Negeri Autis Center Kota Bengkulu pada umumnya sangat senang ketika mengikuti pelajaran Penjasorkes akan tetapi karena keterbatasan kemampuan yang dimiliki para siswa pembelajaran Penjasorkes tidak berjalan dengan baik. Meskipun sarana dan prasarana yang tersedia di sekolah sudah cukup lengkap, materi pembelajaran yang diterapkan oleh guru juga sangat bervariasi. Faktor penghambat yang terjadi di sana adalah ketika kegiatan Penjasorkes digabungkan dengan kelas lain, sedangkan guru yang mengawasi dan mengajarkan kepada siswa hanya satu. Sehingga setiap siswa tidak mendapatkan pelajaran penjas yang maksimal dan guru harus mengikuti kemauan siswa untuk melakukan olahraga dengan materi yang mereka inginkan, biasanya setiap siswa menginginkan materi pembelajaran penjasorkes sesuai yang mereka inginkan tergantung suasana hati mereka dan kemauan siswa pun berbeda-beda dari setiap siswa. Karena jika tidak di ikuti kemauannya biasanya para siswa akan dan tidak mau lagi mengikuti kegiatan penjas. Saat mengamati siswa bermain bola sebagian besar siswa terlihat kesulitan mengarahkan bola itu kearah sasaran dan pada saat menangkap bola siswa ada yang tidak tepat menangkap bola dikarenakan kecepatan reaksi tangan lebih lambat jadi bola tidak bisa ditangkap siswa. Kemampuan motoriknya dan keterampilannya tidak seimbang sehingga bola tidak dapat mengarah bola kearah sasaran dan dalam waktu kecepatan reaksi yang tidak tepat tangan menangkap bola. Pergerakan Koordinasi mata, tangan dan kecepatan reaksi sangat berpengaruh dalam aktivitas olahraga. Contohnya dalam melempar, menangkap dan lain-lain membutuhkan koordinasi mata, tangan dan kecepatan reaksi yang baik maupun tepat. Berdasarkan uraian tersebut maka peneliti berkeinginan untuk meneliti dengan judul "Analisis Kemampuan Koordinasi dan Kecepatan Reaksi Siswa Tuna Grahita dan Autis (Studi Kasus di SLB Negeri Autis Center) Kota Bengkulu".

Penelitian ini diidentifikasikan permasalahannya yaitu Pembelajaran penjasorkes belum maksimal dikarenakan masih digabungkan dengan pelajaran lainnya di SLB Negeri Autis Center Kota Bengkulu. Siswa tuna grahita di SLB Negeri Autis Center Kota Bengkulu pada umumnya tidak bisa mengarahkan suttlecock kearah sasaran. Siswa autis di SLB Negeri Autis Center Kota Bengkulu pada umumnya tidak bisa mengarahkan bola kearah sasaran. Siswa tuna grahita dan autis 
mengalami gangguan kecepatan reaksi pada tubuh. Permasalahan tersebut dibatasi pada Analisis Kemampuan Koordinasi dan Kecepatan Reaksi Siswa Tuna Grahita dan Autis (Studi Kasus di SLB Negeri Autis Center) Kota Bengkulu". Dan dirumuskan menjadi Bagaimana hasil koordinasi siswa tuna grahita dan autis di SLB Negeri Autis Center Kota Bengkulu?. Bagaimana hasil kecepatan reaksi siswa tuna grahita dan autis di SLB Negeri Autis Center Kota Bengkulu? Apakah ada hubungan kemampuan koordinasi dan kecepatan reaksi siswa SLB Negeri Autis Center ? Apakah ada perbedaan kemampuan koordinasi mata dan tangan dan kecepatan reaksi antara Siswa SD Negeri 50 (Anak Normal) dengan SLB Negeri Autis Center (Anak Berkebutuhan Khusus) Kota Bengkulu.?. penelitian ini memiliki tujuan seperti Untuk mengetahui hasil koordinasi siswa tuna grahita dan autis di SLB Negeri

Autis Center Kota Bengkulu. Untuk mengetahui hasil kecepatan reaksi siswa tuna grahita dan autis di SLB Negeri Autis Center Kota Bengkulu. Mengetahui hubungan kemampuan koordinasi dan kecepatan reaksi siswa tuna grahita dan autis di SLB Negeri Autis Center Kota Bengkulu. Untuk mengetahui perbedaan kemampuan koordinasi dan kecepatan reaksi antara SD Negeri 50 (Anak Normal) dengan Siswa SLB Negeri Autis Center (Anak Berkebutuhan Khusus) Kota Bengkulu.

\section{METODE}

Jenis penelitian ini adalah penelitian deskriptif kuantitatif. Metode yang digunakan yaitu dengan menggunakan tes kemampuan koordinasi dan kecepatan reaksi. Arikunto (2010:234) menyatakan bahwa penelitian deskriptif adalah penelitian yang tidak dimaksudkan untuk menguji hipotesis tertentu, tetapi hanya mengambarkan apa adanya tentang suatu variabel, gejala atau keadaan. Dalam penelitian ini nantinya akan mengungkapkan hasil tentang kemampuan koordinasi dan kecepatan reaksi siswa tuna grahita dan autis di SLB Negeri Autis Center Kota Bengkulu. Pada saat melakukan pengamatan di Sekolah Luar Biasa Kota Bengkulu peneliti mendatangi sekolahsekolah untuk melihat dan mengamati anak berkebutuhan khusus disana yang menjadi peneliti tertarik atau tertantang pada kelainan anak tuna grahita dan autis, akan tetapi untuk anak yang autis di sekolah tidak banyak itu pun peneliti temukan di SLB Negeri Autis Center saja. Jadi peneliti mengambil kesimpulan akan melakukan penelitian nantinya di SLB Negeri Autis Center Kota Bengkulu dan tambahan di SD Negeri 50 Kota Bengkulu sebagai perbandingannya. Penelitian dilakukan selama 1 bulan pada tanggal 15 Maret- 31 April 2017. Tes Koordinasi Menurut Arsil (2010:106) menyatakan tes koordinasi adalah tes yang bertujuan untuk mengukur tingkat koordinasi seseorang dengan pusat syaraf, jenis tes ini tes koordinasi mata tangan. Prosedur tes yang disusun sendiri yang telah disusun dengan uji pendahuluan dan telah direkomendasi dari dosen pembimbing utama dan dosen pendamping yaitu. Tujuan: untuk mengukur koordinasi mata tangan siswa tuna grahita dan autis.1). Alat perlengkapan: Lapangan- Bola tenis- Stopwatch - MeteranPluit - Pencatat nilai 2). Pelaksanaan: Peserta tes berdiri berhadapan dengan peneliti dengan jarak 5 mater, Pada saat melakukan tes melempar dan menangkap, peserta tes melakukan lemparan kearah peneliti dan peneliti melempar kembali kearah peserta tes maka peserta tes menangkap bola itu kembali. Nilai jika tes melempar dan menangkap bisa dikuasai oleh peserta tes itu yang diambil. Peserta diberi kesempatan untuk melempar bola kea rah sasaran dan menangkapnya kembali sebanyak 2 kali ulangan hasil yang terbanyak itulah 
yang diambil nantinya.- Waktu melakukan tes adalah 30 detik. 3). Penilaian: - Jika melempar dan menangkap bisa ditangkap oleh peserta maka nilainya 1 . Diberikan kesempatan dua kali hasil terbanyak dalam melakukan tes yang akan diambil.4). Nilai validitas dan reliability. Uji coba pendahuluan instrumen yang telah dilakukan didapatkan validitas sebesar 0,86 dan nilai reliabilitas sebesar 0,81.Tes kecepatan reaksi: 1) Instrumen Reaksi di ukur dengan menggunakan Whole Body Reaction, tujuan untuk mengukur kecepatan reaksi. Alat yang digunakan whole body reaction, alat tulis formulir tes. Pelaksanaan pada saat alat on, testi berdiri pada atas alas tumpu yang tersedia,pandangan kea rah sensor yang akan mengeluarkan cahaya, ketika lampu menyala testisecepatnya melakukan reaksi dengan membuka kedua kaki atau mengeluarkankedua kaki dari alas tumpu, satuan alat ini adalah detik.2). Penilaian dilakukan sebanyak 2 kali diambil yang terbaik.3).Nilai validitas tes whole body reaction time sudah baku karena tes ini mengunakan alat yang telah di uji coba dari para ahli dan dikeluarkan dari perusahan.Sebelum mengetahui hasil hubungan kecepatan reaksi dengan koordinasi siswa tuna grahita dan autis di SLB Negeri Autis Center Kota Bengkulu, maka terlebih dahulu dilakukan uji korealasi hubungan yang akan diuraikan.

\section{HASIL DAN PEMBAHASAN}

Hasil

Hasil penelitian kemampuan koordinasi dan kecepatan reaksi Siswa Tuna Grahita, Autis di SLB Negeri Autis Center Kota Bengkulu dan mencari hasil perbedaan kemampuan koordinasi dan kecepatan reaksi antara anak normal (SD Negeri 50 Kota Bengkulu) dengan anak berkebutuhan khusus (SLB Negeri Autis Center Kota bengkulu). Setelah dilakukan penelitian yang mana hasil penelitian kemampuan koordinasi dan kecepatan reaksi dengan tes lempar tangkap bola tenis kearah sasaran dan tes kecepatan reaksi menggunakan alat whole body reaction yaitu sebagai berikut :

Hasil Tes Kemampuan Koordinasi Siswa Tuna Grahita dan Autis di SLB Negeri Autis Center Kota Bengkulu

Berdasarkan hasil tes kemampuan koordinasi yang telah dilakukan dapat dideskripsikan kemampuan koordinasi siswa tuna grahita sebanyak 20 siswa dan autis sebanyak 10 siswa di SLB Negeri Autis Center Kota Bengkulu sebanyak 30 siswa sebagai berikut : Hasil tes kemampuan koordinasi siswa tuna grahita yang masuk dalam kategori Baik Sekali sebanyak siswa atau sebesar 0\%, kategori Baik sebanyak 2 siswa atau sebesar $10 \%$, kategori Sedang sebanyak 7 siswa atau sebesar 35\%, kategori Kurang sebanyak 8 siswa atau sebesar 40\%, dan kategori Kurang Sekali 3 atau sebesar 15\%, Bisa dikatakan dalam pengambilan hasil tes ini siswa tuna grahita yang masih belum fokus bola masih ada yang jatuh dan tidak tearah kesasaran didepannya. Hasil kemampuan koordinasi siswa autis yang masuk dalam kategori Baik Sekali sebanyak siswa atau sebesar 0\%, kategori Baik sebanyak 2 siswa atau sebesar 20\%, kategori Sedang sebanyak 3 siswa atau sebesar 30\%, kategori Kurang sebanyak 5 siswa atau sebesar 50\%, dan kategori Kurang Sekali 0 atau sebesar 0\%. Siswa autis ini saat melakukkan gerakan lempar tangkap bola belum bagus gerakannya jadi hasil yang didapatkan belum maksimal dan apabila nantinya di latih koordinasi siswa bisa lebih baik.

Hasil Tes Kemampuan Kecepatan Reaksi Tuna Grahita dan Autis di SLB Negeri Autis Center Kota Bengkulu

Berdasarkan hasil perhitungan dari hasil penelitan dapat dideskripsikan kemampuan kecepatan reaksi menggunakan alat Whole Body Reaction yang diambil dari alat tes 
tersebut Satuan detik atau perdetiknya pergerakan seseorang yang ditelit berpindahnya posisi awal hingga berpindah kearah matras yang telah ada didepan,belakang dan samping kanan-kiri. Penelitian ini mengambil subjek diSLB Negeri Autis Center Kota Bengkulu ialah siswa tuna grahita sebanyak 20 siswa dan siswa autis sebanyak 10 siswa di SLB Negeri Autis Center Kota Bengkulu semuanya sebanyak 30 siswa sebagai berikut: Berdasarkan hasil tes kemampuan kecepatan reaksi siswa tuna grahita SLB Negeri Autis Center Kota Bengkulu yang masuk dalam kategori Istimewa sebanyak 0 siswa atau sebesar 0\%, Sangat Baik sebanyak 0 siswa atau sebesar $0 \%$, kategori Baik sebanyak 1 siswa atau sebesar $5 \%$, kategori Sedang sebayak 2 siswa atau sebesar 10\%, kategori Kurang sebanyak 3 siswa atau sebesar $15 \%$, dan kategori Kurang Sekali 14 atau sebesar 70\%, siswa tuna grahita dalam melakukan gerakan ini masih buruk karena siswa sering melamun dan keterbatasan berfikir jadinnya gerakan lambat.

Hasil tes kemampuan kecepatan reaksi siswa autis SLB Negeri Autis Center Kota Bengkulu yang masuk dalam kategori Istimewa sebanyak 0 siswa atau sebesar $0 \%$, Sangat Baik sebanyak 0 siswa atau sebesar $0 \%$, kategori Baik sebanyak 0 siswa atau sebesar 0\%, kategori Sedang sebayak 1 siswa atau sebesar $10 \%$, kategori Kurang sebanyak 2 siswa atau sebesar 20\%, dan kategori Kurang Sekali 7 atau sebesar $70 \%$, dalam tes ini siswa autis sering lambat dalam menggerakan tubuhnya karena siswa kurang fokus siswa melamun dulu sebelum menggerkan tubuhnya. Hasil Hubungan Kecepatan Reaksi (X) dengan Koordinasi (Y) Siswa Tuna Grahita dan Autis SLB Negeri Autis Center Kota Bengkulu Sebelum mengetahui hasil hubungan kecepatan reaksi dengan koordinasi siswa tuna grahita dan autis di SLB
Negeri Autis Center Kota Bengkulu, maka terlebih dahulu dilakukan uji korealasi hubungan yang akan diuraikan sebagai berikuit : Berdasarkan analisis data uji korelasi dapat diketahui bahwa hasil yang didapatkan tes kemampuan kecepatan reaksi dengan koordinasi $r_{\text {hitung }}=0,718$ dan $t_{\text {hitung }}=0,361$ untuk lebih jelasnya dapat dilihat pada tabel.5 di bawah ini :

Hasil Hubungan Tes Kecepatan Reaksi dengan Koordinasi

Tabel 1.

\begin{tabular}{||l||l||l||l||}
\hline \hline Jenis & $\begin{array}{l}\text { Nilai } \\
\text { Hitung }\end{array}$ & $\begin{array}{l}\text { Nilai } \\
\text { Tabel }\end{array}$ & $\begin{array}{l}\text { Kesimpula } \\
\mathbf{n}\end{array}$ \\
\hline \hline Nilai Uji r & 0,718 & 0,361 & Positif \\
\hline
\end{tabular}

Dari tabel diatas dapat dilihat bahwa rhitung lebih besar dari pada $r_{\text {tabel }}$ dimana $r_{\text {hitung }}=$ $0,718>r_{\text {tabel }}=0,361$ berarti ada hubungan yang positif antara kecepatan reaksi dengan koordinasi Siswa Tuna Grahita dan Autis di SLB Berdasarkan tabel interpretasi koofesien korelasi berarti tingkat hubungannya berada pada tingkat hubungan yang kuat.

Hasil Perbedaan Kemampuan Koordinasi dan Kecepatan Reaksi Siswa SD Negeri 50 (Anak Normal) dengan SLB Negeri Autis Center (Anak Berkebutuhan Khusus) Kota Bengkulu

Sebelum mengetahui hasil perbedaan kemampuan koordinasi dan kecepatan reaksi siswa SD Negeri 50 (Anak Normal) dengan SLB Negeri Autis Center (Anak berkebuthan Khusus) Kota Bengkulu, maka terlebih dahulu dilakukan uji korelasi diuraikan sebagai berikuit :

a. Hasil Perbedaan Kemampuan Koordinasi Siswa SD Negeri 50 (Anak Normal) dengan SLB Negeri Autis Center (Anak Berkebuthan Khusus) Kota Bengkulu 
b. Berdasarkan analisis data korelasi dapat diketahui bahwa 14,43 sebagai hasil hitung uji t dan 1,697 sebagai hasil t tabel Untuk lebih jelasnya dapat dilihat pada tabel. 6 di bawah ini

Tabel. 2

Hasil Perbedaan Kemampuan Koordinasi Anak Normal dengan Anak Berkebutuhan Khusus

\begin{tabular}{|l|l|l|}
\hline Jenis & Nilai hitung & Nilai tabel \\
\hline Uji t & 14,43 & 1,697 \\
\hline
\end{tabular}

Dari tabel. di atas dapat diketahui nilai $\mathrm{t}$ hitung lebih besar dari pada nilai $t$ tabel $(14,43>1,697)$, maka dapat disimpulkan bahwa terdapat perbandingan yang cukup besar dan signifikan antara koordinasi Siswa SD Negeri 50 (Anak Normal) dengan SLB Negeri Autis Center (Anak Berkebuthan Khusus) Kota Bengkulu.

Hasil Perbedaan Kemampuan Kecepatan Reaksi Siswa SD Negeri 50 (Anak Normal) dengan SLB Negeri Autis Center (Anak Berkebutuhan Khusus) Kota Bengkulu

Berdasarkan analisis data korelasi dapat diketahui bahwa 0,346 sebagai hasil hitung uji t dan 1,697 sebagai hasil t tabel Untuk lebih jelasnya dapat dilihat pada tabel. 8 di bawah ini:

Tabel 3.

Hasil Perbedaan Kemampuan Kecepatan Reaksi

\begin{tabular}{|l|c|l|}
\hline Jenis & Nilai hitung & Nilai tabel \\
\hline Uji t & 0,346 & 1,697 \\
\hline
\end{tabular}

Dari tabel di atas dapat diketahui nilai t hitung lebih besar dari pada nilai t tabel $(0,346<$ 1,697), maka dapat disimpulkan bahwa tidak terdapat perbandingan, kecepatan reaksi Siswa SD Negeri 50 (Anak Normal) dengan SLB Negeri Autis Center (Anak Berkebutuhan Khusus) Kota Bengkulu.

\section{Pembahasan}

Hubungan Kemampuan Koordinasi dan Kecepatan Reaksi Siswa SD Negeri 50 dengan SLB Negeri Autis Center Kota Bengkulu. Kemampuan koordinasi apabila baik biasanya melakukan gerakan-gerakannya tidak kaku, mengeluarkan tenaga sedikit dan gerakannya efisien. Dalam koordinasi matatangan akan menghasilkan timing dan akurasi, koordinasi suatu kemampuan biomotorik yang sangat komplek, saling berhubungan dengan kecepatan, kekuatan, daya tahan, dan kelentukan. Berdasarkan hail perhitungan diperoleh bahwa rhitung lebih besar dari pada $r_{\text {tabel }}$ dimana $r_{\text {hitung }}=0,718>r_{\text {tabel }}=0,361$, maka dapat disimpulkan terdapat tingkat hubungan yang kuat dan positif antara kemampuan kecepatan reaksi dengan koordinasi siswa SD Negeri 50 dan SLB Negeri Autis Center Kota Bengkulu. Menurut Harsono (1988:219) menyatakan koordinasi erat hubungannya dengan kecepatan, kekuatan, daya tahan, dan fleksibilitas. Seperti yang sudah diterangkan di atas kecepatan, kekuatan,daya tahan, kelentukan, balance, dan ritme, semua menyumbang dan berpadu didalam koordinasi gerak, oleh karena itu sama lain memang mempunyai hubungan erat. Kalau salah satu unsur tidak ada, atau kurang berkembang maka hal ini akan berpengaruh terhadap kesempurnaan koordinasi. Menurut teori diatas terdapat hubungan yang erat antara koordinasi mata dan tangan dengan kecepatan reaksi, sebab kecepatan reaksi membutuhkan koordinasi mata dan tangan yang baik dan dibuktikan dengan semakin baik koordinasi mata dan tangan seorang anak maka semakin baik juga hasil kecepatan reaksinya. 
Perbedaan Kemampuan Koordinasi dan Keceapatan Reaksi Siswa SD Negeri 50 (Anak Normal) dan SLB Negeri Autis Center Kota Bengkulu (Anak Berkebutuhan Khusus). Kemampuan koordinasi siswa pasti ada perbedaannya dikarenakan tidak semua orang tingkat koordinasi baik maka dari itu telah dilakukan pembuktiannya antara siswa normal yaitu siswa SD Negeri 50 dengan siswa tidak normal atau berkebutuhan khusus SLB Negeri Autis center Kota Bengkulu. McGee (1979) dalam Harsono (1988:220) berpendapat bahwa koordinasi adalah kemampuan untuk memadukan berbagai macam gerakan ke dalam satu atau lebih pola gerak khusus. Bisa dikatakan kemampuaan koordinasi siswa normal lebih baik dibandingkan dengan siswa tidak normal. Berdasarkan data diperoleh nilai $t$ hitung lebih besar dari pada nilai $t$ tabel $(14,43>$ 1,697), maka dapat disimpulkan bahwa terdapat perbedaan yang cukup besar dan signifikan antara koordinasi anak normal dengan anak berkebutuhan khusus. Kecepatan adalah kemampuan sesorang dalam mengarahkan gerak tubuh atau bagianbagian tubuhnya melalui suatu ruang gerak tertentu (Nur hasan 1983:240). Dalam rangkaian pengertian bahwa kecepatan gerak ada hubungan erat antara waktu dan jarak. Kecepatan merupakan yang ada pada diri seseorang untuk dilakukakan gerakkan berkesinambunagan dalam bentuk yang sama dan dilakukan dalam waktu yang singkat.

Dalam penelitian yang menggunakan metode deskriptif maka apa yang didapat maka itulah yang akan dijelaskan, hasil yang didapat dari kecepatan reaksi anak normal dengan anak Berkebutuhan Khusus, Berdasarkan tabel.14 diperoleh nilai t hitung lebih kecil dari pada nilai t tabel $(0,346<$ 1,697), maka dapat disimpulkan bahwa tidak terdapat perbedaan kecepatan reaksi antara anak normal dengan anak berkebutuhan khusus.

\section{PENUTUP}

\section{Simpulan}

Berdasarkan hasil penelitian dan pembahasan yang telah diuraikan pada bab sebelumnya, maka dapat disimpulkan sebagai berikut :

a. Kemampuan Koordinasi Siswa Tuna Grahita dan Autis di SLB Negeri Autis Center Kota Bengkulu. Berdasarkan hasil perhitungan tes siswa tuna grahita diperoleh rata-rata kemampuan koordinasi masuk kategori kurang sebanyak $40 \%$. Siswa autis diperoleh rata-rata kemampuan koordinasinya masuk kategori kurang sebanyak $50 \%$.

b. Kemampuan Kecepatan Reaksi Siswa Tuna Grahita dan Autis di SLB Negeri Autis Center Kota Bengkulu. Berdasarkan hasil perhitungan tes siswa tuna grahita rata-rata kemampuan kecepatan reaksi masuk kategori kurang sekali sebanyak $70 \%$, dan siswa autis rata-rata kemampuan kecepatan reaksi masuk kategori kurang sekali sebanyak $70 \%$. Jadi kemampuan kecepatan reaksi siswa tuna grahita dan autis masih sangatlah buruk dikarenakan keterbatasan mereka merespon.

c. Hubungan Kemampuan koordinasi dan kecepatan reaksi Siswa Tuna Grahita dan Autis SLB Negeri Autis Center Kota Bengkulu. Hasil perhitungan terdapat hubungan yang kuat dan positif antara kemampuan koordinasi dan kecepatan reaksi Siswa Tuna Grahia dan Autis SLB Negeri Autis Center Kota Bengkulu dilihat dari rhitung lebih besar dari pada $r_{\text {tabel }}$ dimana $r_{\text {hitung }}=0,718>r_{\text {tabel }}=$ 0,361 . 
d. Perbedaan Kemampuan Koordinasi dan Kecepatan Reaksi Siswa SD Negeri 50 dan SLB Negeri Autis Center Kota Bengkulu. Hasil perhitungan terdapat perbedaan yang cukup besar dan signifikan antara Koordinasi Siswa SD Negeri 50 dengan SLB Negeri Autis center Kota Bengkulu dilihat dari nilai $t$ hitung lebih besar dari pada nilai $t$ tabel $(14,43>1,697)$ dan hasil perhitungan tidak terdapat perbedaan kecepatan reaksi antara Siswa SD Negeri 50 dengan SLB Negeri Autis Center Kota Bengkulu dilihat dari nilai $\mathrm{t}$ hitung lebih kecil dari pada nilai $\mathrm{t}$ tabel $(0,346<1,697)$.

\section{Saran}

Berdasarkan kesimpulan di atas, maka saran yang diberikan antara lain :

a. Bagi sekolah khususnya anak SLB dan SD Negeri 50 Kota Bengkulu untuk dapat mengembangkan permainan dengan menggunakan bola ataupun dengan mainan lainnya dalam meningkatkan kualitas motorik anak agar senang bergerak dan berbagai modivikasi permainan lainnya.

b. Bagi dosen atau guru pendidikan jasmani dan olahraga kiranya dapat menganalisa variabel-variabel lain untuk meningkatkan kebugaran anakanak untuk kedepannya.

c. Bagi peneliti yang ingin melanjutkan penelitian ini agar dapat dijadikan sebagai bahan informasi, referensi dan populasi atau sampel yang berbeda supaya mendapatkan hasil yang lebih banyak lagi.

\section{DAFTAR PUSTAKA}

Arma Abdoellah. (1996). Pendidikan Jasmani Adaptif. Jakarta: Departemen Pendidikan dan Kebudayaan Direktorat Jenderal Pendidikan Tinggi Proyek Pendidikan Tenaga Kerja Akademik.

Arsil, (2010). Evaluasi Pendidikan Jasmani dan Olahraga. Malang. PT. Wineka Media.

Bandi Delphie. (2006). Pembelajan Anak Berkebutuhan Khusus. Bandung: PT. Refika Aditama.

Estri Dwi Pramugar. (2016). Koordinasi Mata tangan dan Kaki Siswa TunaGrahita Kelas Atas SLB Negeri 1 Yogyakarta. Skripsi.pdf. Fakultas Ilmu Keolahragaan. Universitas Negeri Yogyakarta.

Hadis. (2006). Pendidikan Anak Berkebutuhan Khusus Autistik. Bandung: Alfabet. IKAPI.

Harsono. (1988). Coaching dan aspek-aspek psikologis dalam coaching. Jakarta: CV. Tambak Kusuma.

Mohamad Ali. (2009). Ilmu dan Aplikasi Pendidikan. Jakarta: PT. Imperial Bhakti Utama.

Suharsimi Arikunto. (2006). Prosedur Penelitian Suatu Pendekatan Praktik. Jakarta:PT. Rineka Cipta.

Tangkudung, James. (2012). Kepelatihan Olahraga Pembinaan Prestasi Olahraga. Jakarta: Cerdas jaya ,(2016).Macam-macam

Metodologi Penelitian. Jakarta: Lensa Media Pustaka Indonesia 